\title{
On-farm assessment of selected dual-purpose groundnut (Arachis hypogae) cultivars for food and feed
}

\author{
A. T. Omokanye ${ }^{1,4}$, P. E. Olorunju ${ }^{2}$, O. S. Onifade ${ }^{1,5}$, and L. Olaosebikan ${ }^{3}$ \\ 'National Animal Production Research Institute, Ahmadu Bello University, P. M.B. 1096, Shika, \\ Zaria, Nigeria. \\ ${ }^{2}$ Institute for Agricultural Research, Ahmadu Bello University, Samaru, Zaria, Nigeria. \\ ${ }^{3}$ Department of Animal Science, Ahmadu Bello University, Samaru, Zaria, Nigeria. \\ ${ }^{4}$ Centre for Farming Systems Research, University of Western Sydney, Locked Bag \# 1797, Penrith \\ South DC NSW 1797, Australia. \\ ${ }^{5}$ Department of Pasture and Range Management, University of Agriculture, Abeokuta, Nigeria.
}

\begin{abstract}
Ten field trials were conducted on farmers' fields in five villages in sub humid environment of northern Nigeria during the 1998 and 1999 cropping seasons to test the performances of improved groundnut cultivars for forage and seed production. Farmers' preferences and reasons for preference of the cultivars were also assessed. All the selected (improved) cultivars out yielded the local (control) cultivar. Forage, pod and seed yields were greater for cultivar M343-801A, followed by cutlivar 88-801 and then cultivar M516-791 in that order. With the exception of Ca concentration, other nutritive value indices measured, showed sufficient concentrations for livestock production during the critical periods of low quality and scarce forage materials.
\end{abstract}

Keywords:- Groundnut, cultivars, food, feed, assessmention-farm

\section{Introduction}

Groundnut (Arachis hypogaea $L$ ) is one of the world's most popular and universal crops, cultivated in several countries worldwide as a food crop, primarily for human consumption. Its importance in small-holder farming systems in West and Central Africa cannot be overemphasized where crop-livestock farmers in the sub humid and semi acid zones grow the crop for both seed and fodder. The farmers consider both to be equally important because the fodder is a major dry season feed resource for their livestock, and a source of household income (Olorunju et al., 1996; Williams et al. 299
1996). Groundnut haulms are the most important crop residues used by agropastoralists to supplement fodder during the dry season. In this regard, the small-holder farmers in sub humid zone of West Africa prefer latematuring groundnut cultivars to early maturing types (Olorunju et al., 1996).

Nigeria is the largest producer of groundnut in Africa, accounting for $25 \%$ of the continent production (FAO, 1999). Varieties cultivated in Nigeria vary according to their season length, from early-through medium- to late-maturing types depending largely on ecological zones. 


\section{Omokanye, Olorunju, Onifade and Olaosebikan}

Many farmers grow groundnut as a component of crop mixtures involving cereal crops such as maize, orghum and millet. In northern Nigeria, more farmers are beginning to grow groundnut mainly for haulms especially within the dry sub humid and arid zones (Omokanye et al., 2001). The forage (haulms) after pod harvesting, is extensively fed to ruminants, particularly during the dry season (Powell, 1985; Olorunju et. al., 1996).

In recognition of this fact, researchers at the National Animal Production Research Institute (NAPRI) based at Shika (Northern Nigeria) and International Livestock Research Institute (ILRI) based in Ibadan (South Western Nigeria) were initiated into the Nationally Coordinated Research Project on Groundnut (NCRPG) of the Institute for Agricultural Research (IAR), Samaru (northern Nigeria). Before the involvement of these researchers (Animal Scientist) from NAPRI and ILRI and plant breeders had always selected groundnut varieties mainly for the seeds with less emphasis on fodder yield and food value and how these factors affect the farmers. Recently, these researchers reported on the performance of late-maturing groundnut cultivars in the northern guinea savanna zone of Nigeria (Larbi et al., 1998; Larbi et al. 1999); Omokanye et al., 2001). Outstanding cultivars that were identified from their on-station projects and from the results obtained from the IAR Coordinated Research project (P.E. Olorunju, personal communication) have been multiplied and taken on-farm in different parts of the country, in order to test their performances in relation to farmers' preferences. Such collaboration with farmers could enhance farmers adoption of new cultivars with great potential for forage and seed production. The assumption is that the new on-farm technology seems to be superior to the present farming practice adopted by the farmers. The target areas within the country consist of farms on which common production systems are presently in use and for which the new technology is expected to result in an improved production. The objectives of the study were to (1) introduce selected dual-purpose groundnut cultivars on-farm. (2) evaluate the agronomic performance and farmers' perceptions of dualpurpose groundnut for feed and food and (3) develop an appropriate research approach for long-term, farmer-driven, community-based experimentation in collaboration with researchers at Shika.

\section{Materials and methods}

\section{Experimental site}

The experiment was carried out during the 1998 and 1999 cropping seasons (JuneOctober) in 5 villages, all within the proximity of National Animal Production Research Institute (NAPRI), Shika, in the sub humid zone of Nigeria (Latitude $11^{\circ} 15^{\mathrm{N}} \mathrm{N}$, Longitude $7^{\circ} 32^{\prime} \mathrm{E}$, altitude $610 \mathrm{~m}$ above sea level). The climate of the study area is characterized by a well-defined wet and dry season. The wet season begins in April/May and ends in the late September/mid October. The highest mean maximum air temperature of $36^{\circ} \mathrm{C}$ was recorded in April while the lowest mean minimum temperature of $11.5^{\circ} \mathrm{C}$ occurred in December/January. The ferruginous tropical soils of the study site were derived from sandy parent material and crystalline acid rock (Klinkenberg and Higgins 1968). Kowal (1968) described the soil as a well-drained sandy loam with a clay fraction consisting mainly of kaolinite and small quantities of illite, deficient in $\mathrm{N}$ and $\mathrm{P}$. The mean long-term annual rainfall (1985-1997) and rainfall during the trail years are shown in Table 1.

\section{Field planting and management procedures}

Ten on-farm trials were conducted at Shika and its environs. In each trial. four late-maturing groundnut cultivars were compared for seed and forage production. Of the four cultivars. 


\section{Testing groundnut cultivars on-farm for food and feed}

three outstanding improved cultivars (88-80I, M343-80IA and M516-79I) which have been selected from NCRPG were used. The fourth (a common and popular) cultivar provided by the farmers was used as local (control) check. Each trial occupied an area of $400 \mathrm{~m}^{2}$ divided into four equal $100 \mathrm{~m}^{2}$ plots. On three of these plots the three improved cultivars were used, while on the fourth plot the farmers'usual cultivar was used. This was aimed at providing an avenue for a comparative side-by-side evaluation of the cultivars by the local farmers. The cultivars were sown on June 19 and 21 in 1998 and 1999, respectively on manually ridged land spaced $75 \mathrm{~cm}$ apart and $10 \mathrm{~m}$ long. Sowing was done by hand at the rate of 2 seeds per drill, $20 \mathrm{~cm}$ between plant stands. A basal application of $25 \mathrm{~kg} / \mathrm{ha} \mathrm{P}^{2} \mathrm{O}^{5}$ in the form of single superhosphate was made once at sowing. Weed growth was controlled twice, by manual hoeing. All plots were prepared, planted and managed by the farmers and these operations, were monitored by a team of scientists/technicians from NAPRI. Prior to the commencement of the trial in 1998, the experimental areas had either been cultivated to sorghum alone, or a combination of early maize/pepper, maize/cowpea, rice/maize, maize/cowpea, or maize/soghum/cowpea. All the four cultivars tested on-farm were replicated on-station at NAPRI for demonstration/field visit purpose.

At pod harvesting, 2- plants from the 4 inner rows/ridge of each cultivar were randomly hand-pulled (with the aid of a hoe) from each plot for determination of forage and seed yields on 21 October in 1998 and on 26 October in 1999. Pods were picked from the plants, sundried (for 5-7 days) to constant weight and shelled to estimate seed yield. Shelling percentage was estimated as the ratio of seed weight to unshelled pod weight multiplied by 100 . The forage component was hand separated into leaf and stem fraction and the weight of each fraction was recorded and sun-dried for about 7 days for dry matter yield estimation. The stem fraction included the roots and pegs. The fractions were used to determine the leaf: stem ratio. At pod harvesting each year, structured questionnaires were administered at each village to assess farmers preference. In 1998, all the farmers were invited to NAPRI for a field visit in order to assess the performance of these varieties on-station. It was also a forum for further discussions on the benefits of the new package of technologies on dual-purpose groundnut cultivars selection trial for seed and fodder production in small-holder croplivestock systems. All inputs required (treated seeds and fertilizer) were provided to each farmer at the beginning of each cropping season. All plots were well-labeled.

\section{Chemical analysis of whole plant samples}

Oven-dried forage (whole plant) samples were ground with Christy and Norris Laboratory mill using a $1 \mathrm{~mm}$ mesh. These are subsequently analyzed for $N, P, K$, and Ca concentrations, $N$, $\mathrm{P}$, and $\mathrm{K}$ concentrations were determine on $\mathrm{DM}$ basis according to the standard Micro-Kjedahl and colorimetric (Vanado-molbdate) methods, respectively (AOAC 1976). Calcium was determined by the technique described by Ranjhan and Krishna (1980) followed by absorption spectrometry technique using a double beam digital photometer. Neutral Detergent Fiber (NDF) and Acid Detergent Fiber (ADF) were determined according to the procedures outlined by Goering and Van Soest (1970).

\section{Data Analysis}

For the statistical analysis, a single replication on each cultivar on each farm was used and the data anlysed using SAS GLM procedures (SAS, 1988) as a randomized block design with farms as blocks. This was because blocking by farms would provide a wider coverage of the target area than would be the case with multiple 


\section{Omokanye, Olorunju, Onifade and Olaosebikan}

Table 1 Mean long-term (1985-1997) and annual rainfall during the trial years (1998 and 1999) at Shika, sub humid Nigeria.

\begin{tabular}{llll}
\hline Month & Long-Term & 1998 & 1999 \\
\hline April & $51.3(7)$ & $731(5)$ & $40.6(4)$ \\
May & $96.0(10)$ & $125.0(12)$ & $64.1(11)$ \\
June & $151.1(13)$ & $110.9(12)$ & $182.9(13)$ \\
July & $217.3(13)$ & $162.3(15)$ & $214.9(19)$ \\
August & $268.3(13)$ & $429.6(22)$ & $171.2(25)$ \\
September & $180.5(16)$ & $201.7(21)$ & $237.1(23)$ \\
October & $52.6(6)$ & $64.6(10)$ & $62.0(7)$ \\
Total & $1017.1(86)$ & $1167.2(97)$ & $972.8(102)$ \\
\hline
\end{tabular}

$*$ Values in parentheses are number of rainy days.

replication on only a few farms. For the values of yield emergence and leaf stem ratios which were in percentages angular transformation was used at $P=0.05$. Simple correlation coefficients between agronomic traits and nutritive value indices were calculated across the two cropping seasons.

\section{Results and discussion}

Field emergence and yields

The mean field emergence taken at plant establishment after 30 days of planting was generally impressive $(>80 \%$ ) (Table 2 ). Field emergence varied insignificantly $(P>0.05)$ from $85 \%$ for cultivar $88-801$ to $90 \%$ for cultivar M516-79I. Emergence did not differ significantly $(\mathrm{P}<0.05)$ between trial years. Over the two years, negligible amount of mortality of field emerged seedlings $(<5 \%)$ which was caused mainly by termites was recorded on three out of the ten farms. The impressive emergence and survival of these cultivars further confirms earlier findings that the

cultivars tested are adapted to local conditions in parts of sub humid Nigeria (Omokanye et al., 2001).

The mean forage was lowest $(3346 \mathrm{~kg} / \mathrm{ha})$ with the control check and highest $(6231 \mathrm{~kg} / \mathrm{ha})$ with cultivar M343-80IA (Table 2). With the exception of control check, the improved cultivars recorded forage yields above $5000 \mathrm{~kg} / \mathrm{ha}$. The control check had the lowest leaf: stem ratio (37\%) and M343-801A the highest (48\%) (Table 2). Forage yield and leaf: stem ratios were slightly better in 1999 than 1998. A cursory look at Figure 1 shows that forage yields of cultivars 88-80I, M343-80IA, M516-79I and control at different locations (farms) varied respectively from 5645 to $6381 \mathrm{~kg} / \mathrm{ha}, \quad 5702$ to $6987 \mathrm{~kg} / \mathrm{ha}, 4680$ to $6041 \mathrm{~kg} / \mathrm{ha}$ and 2878 to $3707 \mathrm{~kg} / \mathrm{ha}$. However, when pooled over cultivars, forage yield varied insignificantly $(\mathrm{P}>0.05)$ from $4899 \mathrm{~kg} / \mathrm{ha}$ for location 7 (farm 7) to $5449 \mathrm{~kg} / \mathrm{ha}$ for farm 6 . Only 3 farms had forage yield less than $5000 \mathrm{~kg} / \mathrm{ha}$.

Table 2 Mean forage and seed yields of groundnut (Arachis hypogaea) cultivars tested on-farm in a part of sub humid Nigeria

\begin{tabular}{llllllll} 
Varieties & $\begin{array}{l}\text { Field } \\
\text { emergence }(\%\end{array}$ & $\begin{array}{l}\text { Forage } \\
(\mathrm{kg} / \mathrm{ha})\end{array}$ & yield & $\begin{array}{l}\text { Leaf: } \\
(\%)\end{array}$ & $\begin{array}{l}\text { tem } \\
(\mathrm{kg} / \mathrm{ha})\end{array}$ & $\begin{array}{l}\text { Pod } \\
(\%)\end{array}$ & $\begin{array}{l}\text { Seed yield } \\
(\mathrm{kg} / \mathrm{ha})\end{array}$ \\
\hline 88.801 & 85 & 5958 & 46 & 2295 & 64 & 1469 \\
M343-801 & 88 & $623 \mathrm{j}$ & 48 & 2367 & 65 & 1539 \\
M516-791 & 90 & 5257 & 45 & 2092 & 60 & 1255 \\
Check & 89 & 3346 & 42 & 1640 & 62 & 1017 \\
L.SD $(\mathrm{P}=0.05)$ & 8 & 441 & 8 & 258 & 7 & 184 \\
\hline
\end{tabular}




\section{Testing groundnut cultivars on-farm for food and feed}

Table 3 Forage nutritive value of groundnut (Arachis hypogaea) cultivars tested on-farm in a part of sub humid Nigeria

\begin{tabular}{llllllll}
\hline Varieties & $\mathrm{N}$ & $\mathrm{P}$ & $\mathrm{K}$ & $\mathrm{Ca}$ & $\mathrm{Ca}: \mathrm{P}$ & $\mathrm{NDF}$ & ADF \\
\hline $88-801$ & 3.01 & 0.69 & 4.94 & 3.39 & 4.91 & 51.3 & 47.3 \\
M343-801A & 2.97 & 0.73 & 4.73 & 2.81 & 3.85 & 50.3 & 49.5 \\
M516-791 & 2.31 & 0.47 & 4.66 & 2.64 & 5.62 & 48.2 & 53.0 \\
Check & 2.42 & 0.56 & 3.68 & 1.32 & 2.36 & 42.7 & 52.1 \\
LSD $(\mathrm{P}=0.05)$ & 0.51 & 0.17 & 1.03 & 0.68 & 0.89 & 4.0 & 5.3 \\
\hline
\end{tabular}

Pod yield was greater than $2000 \mathrm{~kg} / \mathrm{ha}$ for the three improved cultivars tested and less for the control (Table 2). The lowest add highest pod yields were respectively 1640 and $2367 \mathrm{~kg} / \mathrm{ha}$. Except for the control check and M517-79I, pod yields did not differ much between years. Shelling percentage varied from 60 to $65 \%$. Cultivar M343-80IA had the highest seed yield, followed by 88-80I, then M516-79I and the control check in that order. The seed yields of cultivars 88-801, M343-80I, M516-79I and control at different farms varied respectively from 1363 to $1620 \mathrm{~kg} / \mathrm{ha}, 1374$ to $1514 \mathrm{~kg} / \mathrm{ha}$, 981 to $1393 \mathrm{~kg} / \mathrm{ha}$ and 853 to $1143 \mathrm{~kg} / \mathrm{ha}$ (Figure 2). However, when pooled over cultivars, seed yields from $1161 \mathrm{~kg} / \mathrm{ha}$ for farm 8 to $1337 \mathrm{~kg} / \mathrm{ha}$ for farm 10 were recorded. Only 3 farmers had forge yield less than $5000 \mathrm{~kg} / \mathrm{ha}$. In general mean pod yield and shelling percentage and seed yield in 1999 were relatively higher than in 1998. The slight decrease in the performance of the tested cultivars with respect to forage and pod yields, leaf stem ratios in 1998 in comparison to 1999 could be attributed to higher amount of rainfall received in 1998. Rainfall was higher in August 1998 which was in excess of about $72 \%$ over that of 1999 and $38 \%$ over the long-term average (Table 1). Although the distribution in 1998 was comparable to other years, the excess amount received could have affected growth, pod formation and development. However, average forage and pod yields and leaf stem ratios in the present study are within ranges reported earlier in the same environment (Larbi et. al., 1999; Omokanye et. al. 2001).

\section{Forage quality}

The concentrations of $\mathrm{N}, \mathrm{K}$, and $\mathrm{Ca}$ in forage varied significantly $(\mathrm{P}<0.05)$ between cultivars, but $\mathrm{P}$ concentration was not affected. Cultivar $88-80 \mathrm{I}$ was greater in $\mathrm{N}(3.01 \%), \mathrm{K}(4.94 \%)$, and $\mathrm{Ca}(3.39 \%)$ concentrations while M343-801 and M516-79I were respectively greater in $\mathrm{P}$ concentration $(0.73 \%)$ and $\mathrm{Ca}$ : $\mathrm{P}$ ratios $(5.62)$ (Table 3). The implications of the Ca:P ratios, which were widely above the range of $1: 1-2: 1$ range recommended by Underwood (1981), can only be known when the composition of other feed sources is known. The $\mathrm{N}$ concentrations in forage of the cultivars assessed, even in the control (check) material, were above the critical level of $1.74 \%$ suggested, by NRC (1976) for ruminants production in the dry season. Similarly $\mathrm{P}$ concentrations were above the critical level of $0.12 \%$ suggested by Little (1980). However, all the cultivars were lower than the critical level of $3.5 \% \mathrm{Ca}$ suggested by Minson et al., (1976) for young beef cattle. Comparing the $\mathrm{Ca}$ concentrations from the present studies with other findings elsewhere (Leche et al., 1982, 1985; Bredon et al., 1987), it seemed that the concentrations of $\mathrm{Ca}$ in groundnut forage at pod maturity is generally low and could hardly meet ruminant production requirements. Calcium concentrations in the present study were however higher than those reported by Leche et al. 1982 and Bredon et al., 1987. The higher $\mathrm{Ca}$ concentration in the present study could have resulted from the type of single superphosphate fertilizer applied. The fertilizer contained some amount of $\mathrm{Ca}$ and $\mathrm{Mg}$. Whether the forage Ca concentrations of 
Omokanye, Olorunju, Onifade and Olaosebikan

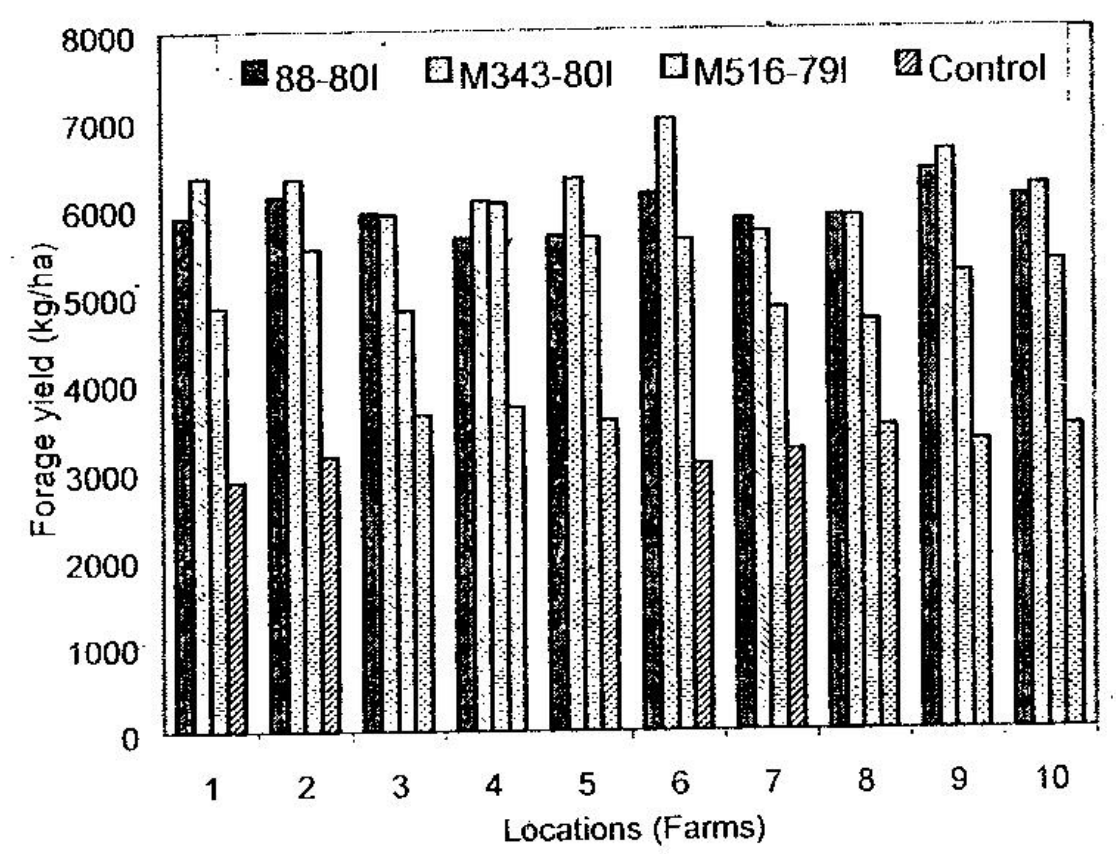

Figure 1 Forage yield of cultivars tested on-farm in a part of sub humid Nigeria

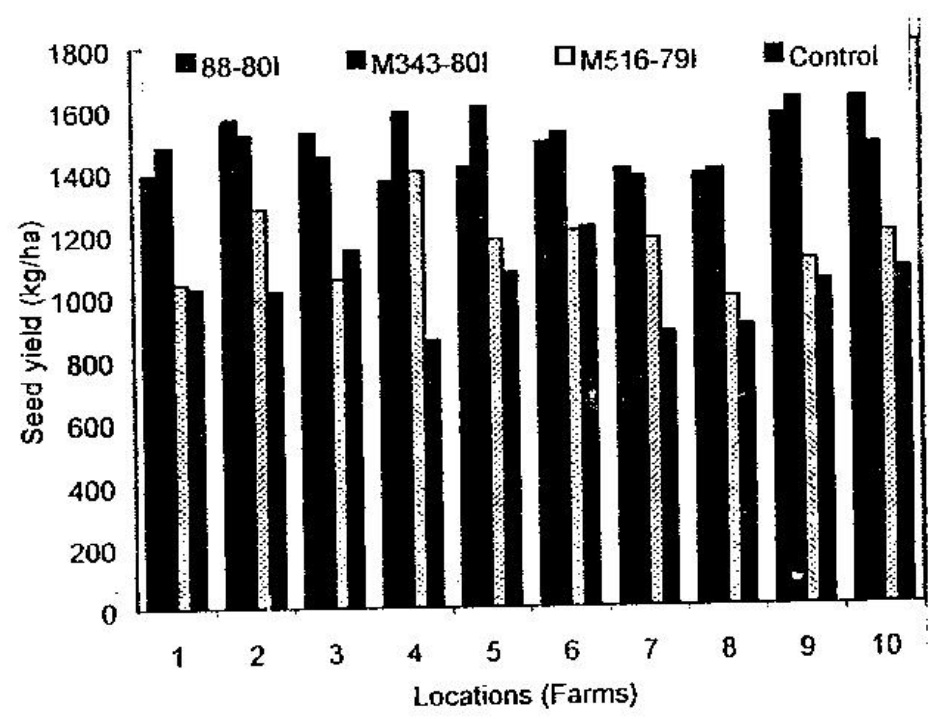

Figure 2 Seed yields of cultivars tested on-farm in a part of sub humid Nigeria 


\section{Testing groundnut cultivars on-farm for food and feed}

groundnut could be enhanced by the addition of $\mathrm{Ca}$ or not needs to be investigated.

In accordance with earlier reports (Chairatanayuth and Taripatananon, 1987), whole forage NDF and ADF concentration varied among cultivars (Table 3 ) and were also within the ranges earlier reported by these authors.

\section{Relationship between agronomic traits and} nutritive indices

There was positive and significant relationship between seed and ( 1 ) forage yields $(r=0.604)$ and (2) pod yields ( $r=0.688$ ). The correlation between forage and seed yield in this study. confirms earlier reports on groundnut (Larbi et al., 1999; Omokanye et al., 2001), and this suggests that forage and seed yields characteristics may be combined in breeding programmes for late maturing groundnut cultivars. The relationships between forage yield and nutritive value of groundnut forage were not very impressive. For instance, forage yield had a significant but weak correlation with $\mathrm{N}(\mathrm{r}=0.286), \mathrm{P}(\mathrm{r}=0.315), \mathrm{Ca}(\mathrm{r}=0.302)$ and NDF $(r=0.308)$. Poor correlation existed between forage yield with either K $(r=0.069)$ or ADF $(\tau=0.126)$.

\section{Farmer preference of cultivars tested}

In 1998, cultivar 88-801 was preferred by 5 of the 10 farmers and the remaining 5 preferred cultivar M343-80IA in 1999, four farmers preferred $88-80 \mathrm{I}$, while the remaining six farmers preferred M343-801. Over the two years, cultivar M343-80IA ranked first and therefore was most preferred followed by cultivar. The reasons behind farmers' preference and selection of M343-80IA and 88$80 \mathrm{I}$ for further cultivation on large scale as indicated by these farmers were: high forage and pod yields, large seed (most especially for M343-80IA) and oil content of nut following local oil extraction. Two farmers however noted that cultivar M516-79I contained slightly higher oil content than those of $88-80 \mathrm{I}$ and M343-80IA. Study is therefore needed to determine the oil content and nutritive indices in the nuts of the cultivar. Determination of residual (cake) quality after oil extraction for the benefit of livestock use is also important. Although, the present study did not determine the oil content of the nuts from the cultivars used, it was gathered from the farmers that the oil content of the nut and cake (residue after oil extraction) from all the cultivars were generally incredible when compared with the cultivars of groundnut they have been used to for years now. Generally, the farmers were impressed by the high forage yield of the improved varieties. Farmers also noted that in addition to the better quality forage for their livestock, the oil and cake would provide a major source of household income. This would also relieve them of worries during the critical periods of scarcity for dry season feeds.

\section{Conclusion}

The on - farm performance of the selected latematuring groundnut cultivars (particularly 8880I and M343-801A) further confirms the potential and reliability of these cultivars in the provision of greater amount of nuts for humans and higher amount of quality feed for livestock production in such humid environments of Nigeria. This was further confirmed by their acceptability by farmers. More farmers indicated their interests in participating in future similar trials.

\section{Acknowledgements}

The authors wish to thank the Director, IAR and NAPRI of Ahamadu Bello University, Zaria. Nigeria, for providing the facilities and permission to publish this work. The assistance of the staff of Forage and Crop Residue Research Programme and Livestock Systems Research Programme of NAPRI in data collection, farm visits and monitoring of the 


\section{Omokanye, Olorunju, Onifade and Olaosebikan}

trials is gratefully acknowledged. The funding of the study, for which we are also grateful, was from the World Bank Assisted National Agricultural Research Projects (NARP) through the Nationally Coordinated Research Project on groundnut at IAR.

\section{References}

AOAC (Association Of Official Analytical Chemist). 1976. Official methods of analysis of the AOAC $12^{\text {th }}$ edition Washington, DC.

Bredon, R. M, Steward, P. G., and Dugmore, T. J. 1987. A manual on the nutritive value and chemical composition of commonly used South African Farm Feeds. Natal Region, Department of Agriculture and Water Supply, South Africa.

Chairatanayuth, P. and Taripatanon, $T$. 1987. Variation in nutritive value of peanut residue. In: Dixion, R. M. (Ed.). Ruminant Feeding Systems Utilizing fibrous Agricultural Residues. International Development Program of Australian Universities and Colleges, Canberra, Australia, pp. 157-160.

FAO, (Food and Agricultural Organization), (1999). FAO quarterly bulletin of statistics Volume 12, 3/4 1999 FAO, Rome, Italy.

Goering, H. K. and Van Soest, P. J. 1970. Forage Fibre Analysis (apparatus, reagents, procedures, and some applications). Agricultural Handbook 379. Agricultural Research Service. USDA, Washington Dc, USA.

Klinkeneberg, $\mathrm{K}$ and Higgins, G. M. 1968. An outline of Northern Nigerian Soils. Nigerian Journal of Science, 2, 91-115.

Kawal, J. 1968. Some physical properties of soils at Samaru, Zaria, and Nigerian: Storage of water and its use by crops. I.
Physical status of soil. Nigerian Agricultural Journal, 5, 13-20.

Larbi, A., Olorunju, P. E., Smith, J. W.. Tanko, R. J. Muhammad, J. $R$ and Adekunle, 1. O. 1999. Groundnut (Arachis hypogaea) for food and fodder in croplivestock systems: forage and seed yields. chemical composition and rumen degradation of leaf and stem fractions of 38 cultivars Animal Feed Science and Technology, 77, 33-47.

Lech, T. E. Groenendyk, G.M., Westwood, N. H. and Jones, M. W. 1982. Composition of Animal Feedstuffs in Australia, Australian Feeds information Centre, Commonwealth Scientific and Industrial Research Organization, Australia, p. 124.

Little, D. A., 1980. Observations on the phosphorus requirement of cattle for growth Research in Veterinary Sciences, 28, 258260.

NRC (National Research Council). 1976. Nutrients requirements of sheep, National Academy of Science, Washington, D. C. USA.

Olorunju, P. E., Ntare, B. R., Babalola, O. A. and Alabi, O. 1996. In: Proceedings of a Workshop on Nationally Coordinated Groundnut Research project, 25-29. September, 1995, Zaria, Nigerian, 47pp. IAR/ABU, Zaira \& ICRISAT, Kano, Nigeria.

Omokanye, A. T., Onifade, O. S., Olorunju, P. E., Adamu, A. M., Tanko, R. J. and Balogun, R. O. 200I. The evaluation of dual-purpose groundnut (Arachis hypogaea) varietis for fodder and seed production at Shika, Nigeria, Journal of-Agricultural Science, Cambridge, 136, 75-79. 


\section{Testing groundnut cultivars on-farm for food and feed}

Powell, M. 1985 Contribution of fractionated crop residues to dry season livestock feed resources in the Abet plains, Central Nigeria, ILCA Newsletter 4: 5-7.

Ranjhan, J. K. and Krishna, G. 1980. Laboratory manuals for nutrition research (Vikas Published House DVT Itt: New Delhi, India).

SAS (Statistical Analysis Systems Institute Inc.) 1988. SAS User's guide: Statistics, Version 6 ed. Statistical Analysis Systems Inc. Cary, NCUSA.
Underwood, E. J. 1981. The mineral nutrition of livestock. (CAD International: Farnham Royal, UK).

Williams, T. O., Fernandez-Rivera, S. and Kelley, T. G. 1996. The influence of socioeconomic factors on availability and utilization of crop residues as animal feed. In: ${ }^{-}$Crop residues in sustainable mixed crop. Livestock farming systems (Ed C. Renard), pp. 25-39, Wallingford: CAB International.

(Received 3 February 2001; Accepted 25 August 2001) 